種類を交換するケースが少なくない様な場合，コリメー 夕の脱着认費いやす時間は労力的な負担となるが，との システムでは比較的スムーズに交換ができ今までの1/10 位の労力ですむ. 又, 感度, 分解能, 一様性のパターン は通常のコリメータとあまり差異はない。取扱上の問題 点は脱着が簡単なため取り替える頻度が多くない物理的 な衝撃の面が多少心配である。

25. 脳 RI アンギオグラフィーにおけるデータ処理の検 討

埼玉医科大学附属病院 核医学診療部 ○沢 良悦 - 比企修一 加藤知明 - 小川 清

デー夕処理に扎ける各 parameterの有用性と脳血管障 害例で特異的な Flip-Flop pattern がアンギオオグフィ 一と T/A curve で一致しなかつた症例々ついて, ROI 設定の方法を変化させ比較検討を行った。

(1)ROI を中大脳動脈領域に設定した場合に，より左右 差を示した。

(2)各 parameter の有効度の高さは MDT, FMTT, BTT, MAT の順であった。

(3)局所血流検查に先立つ，スクリーニング検査として 有用と教える。

\section{6. 肺吸入シンチグラフィーの使用経験}

\section{上都賀総合病院}

\section{○加滕裕安 · 斎藤耕志}

[目的]テクネフチン酸による肺财入シンチグラフィ 一の使用を得ました。使用した装置は超音波ネプライザ 一でアクネフチン酸をエアゾール状として财入させ，肺 の気道状態を把握するととが出来ました

[結論]（1)手技が ${ }^{133} \mathrm{Xe}$ を用いる場合に比較して簡単 (2)局所換気障害の検出，(3)肺血流加換気障害之の区別; (4)楽品が安価, (5)多方向のスキャンが可能，(6)読影に熟 練を要すなおこの検查は補助的診断のためにX線写真， 肺血流スキャン肺機能検查などのデー夕と比較するとと によりいっそう読影隹有利と考えます。污染，被曝の問 題はネブライザ一装䈯にプロテクタをかぶせ，空気の涯 染については収集装䈯を土夫すれば良い。

\section{In vivo ${ }^{99 m} \mathrm{Tc}-\mathrm{RBC}$ の標識率及びホールボディイメ ージの関係}

埼玉医科大学附属病院 核医学钐療部 ○柴山紀子・関 守雄・吉沢漞善

今回我々は，in vivo 赤血球標識法について，PYP の 投与量を変化させ，䅺準率及びホールボディイメーシと の関係から，最適標識条件を求めたので報告する。
PYP は $0.03 \sim 0.2 \mathrm{mg} / \mathrm{kg}$ とし, 標準率の測定はPYP 静注30分後採血飞よる in vitro 法と, ${ }^{99 \mathrm{~m}} \mathrm{TcO}_{4}$ - 静注後 の経時的採血による in vivo 法とを行い比較検討した。 in vivo 法には反㡺をしめるため, $\mathrm{H}_{2} \mathrm{O}_{2}$ を使用した。

PYP の投与量が少ない程標識のスピードが遅いため フリーのテクネ就状腺，霄などに集積し，ホールボデ イイメージを劣下させる。また体内での標識は試験管内 でのそれより6早りととがわかった。PYPの最適投与 量は, $0.2 \mathrm{mg} / \mathrm{kg}$, 約 $1 / 2$ バイヤルであった。

\section{Radioimmunoassayによる血中 Thyroxine-Binding} Globlin (TBG) 測定の基礎的検討

日本ラジオアッセイ研究所

○川田行典・角張茂子・蚛 清 川迅芳則 $\cdot$ 和田政代

TBG は血中 $\mathrm{T}_{4}$ 及ひ $\mathrm{T}_{3}$ の特異的輸送蛋白である。彷 来 TBG の測定は，間接的な測定て限られてきた。今回 RIA-gnost TBG キットを入手する機会を得たので報告 する. Incubation temperature $4^{\circ} \mathrm{C}, 25^{\circ} \mathrm{C}, 37^{\circ} \mathrm{C}$ 打いて のスタンダードカーブは $4^{\circ} \mathrm{C}$ が少し低值の他は良好な結 果が得られ，60分，120分，150分，180分，24時間の比較 では150 分以上の Incubation がよいととが示された。 高濃度値の希勫試験では添付の希釈用血清で希釈すれば 十分と思われた。回収率は 102.0\%となり，Intraassay では標準偏差，変動係数とも満足すべき結果となり， $\mathrm{T}_{4}$ 添加試験では TBG 值に影響を与えないととも 碓認でき た.これから日常臨稆検査に TBG の RIA 法でのdirect assayは有用であると考えられる。

29. Solid Phase Radioimmunoassay による血中 $\mathbf{T}_{4}$ 測 定用キットTETRBEAD-125の基礎的，臨床的検討 国立東京第二病院 核医学センター ○石橋章产・高原淑子 山岓・豊・佳々术由三

$\mathrm{T}_{4}$ の RIA キットである TETRABEAD-125 と現在使 用中の SPAC $\mathrm{T}_{4}$ との比較，基礎的ならびに臨朱的検討 を加えたので報告する.

[結果]Incubation 温度, 時間ヘの影響は少なく，再 現性は低，中，高濃度試料につにて検討したが何れも良 好であった：固取率は 97.02〜101.07\%であった。希釈 試験は 3 者血清で良好な結果を得た。SPAC T 較は，相関係数 0.95 ，回帰直線式 $y=0.939 x+1.115$ 厄 あった。正常值は男子97例で $4.9 \sim 12.4 \mu \mathrm{g} / \mathrm{d} l$, 女子 154 例で $5.1 \sim 13.2 \mu \mathrm{g} / \mathrm{d} l$ でった。また各俟患症例の检討 屯併せて行った. 以上本キットは微量血清で容易に操作 出来，かつ安定した良好なキットと言えよう。 